5. Alternatyvni sposoby vyrishennya trudovykh sporiv. V. Ya. Burak, L. V. Kulachok-Titova, P. D. Pylypenko, N. I. Chudyk-Bilousova; pid red U. Gellmanna, P. D. Pylypenka. Khmelnyczkyj : Khmelnyczkyj universytet upravlinnya ta prava, 2015. $172 \mathrm{~s}$. [in Ukrainian]

6. Pro deyaki aspekty mediaciyi $v$ cyvilnykh i gospodarskykh sporakh vid 21.05.2008: dyrektyva Yevropejskoho parlamentu. URL: https://zakon.rada.gov.ua/laws/show/994_a95 [in Ukrainian]

7. Code du travail. URL: http://codes.droit.org/CodV3/travail.pdf [in French]

8. Pro mediaciyu (poserednycztvo) vid 17. 12. 2004: Zakon Respubliky Bolgariya. URL: https://issuu.com/uccg/docs/25 bulgarian_mediation_state act_ukr [in Ukrainian]

9. Pro mediaciyu: proekt Zakonu Ukrayiny №3504 vid 19.05.2020. URL: http://w1.c1.rada.gov.ua/pls/zweb2/webproc4_1?pf3511=68877 [in Ukrainian]

10. Enykeev, M. Y. Osnovy obshhej yurydycheskoj psykhologyy: ucheb. dlya vuzov. Moskva.: Yuryst, 1996. $631 \mathrm{~s}$. [in Russian]

11. Ustawa $z$ dnia 26 czerwca 1974r. Kodeks pracy. URL: http://prawo.sejm.gov.pl/isap.nsf/DocDetails.xsp?id=WDU19740240141 [in Polish]

O. Terekh, PhD (Law), Teaching Assistant

Taras Shevchenko National University of Kyiv, Kyiv, Ukraine
12. Kodeks zakoniv pro pracyu Ukrayiny v redakciyi vid 20.03.2020. URL: https://zakon rada gov.ua/laws/show/322-08\#top [in Ukrainian]

13. Proekt Trudovogo kodeksu № 2410 vid 08.11.2019. URL: https://w1.c1.rada.gov.ua/pls/zweb2/webproc4_1?pf3511=67331 [in Ukrainian] 14. Pro tretejski sudy: Zakon Ukrayiny vid 11.05.2004. URL: https://zakon.rada.gov.ua/laws/show/170115?find=1\&text=\%D1\%82\%D1\%8 \% $1 \% 83 \% \mathrm{D} 0 \% \mathrm{~B} 4 \% \mathrm{D0} \% \mathrm{BE} \% \mathrm{D} 0 \% \mathrm{~B} 2$ \#Text [in Ukrainian]

15. Terekhov V. Online Mediation: a Game Changer or Much Ado About Nothing?. 2019. \# 3 (2) Access to Justice in Eastern Europe 33-50. URL: http://ajee-journal.com/upload/attaches/att 1569575810.pdf [in English]

16. Ryeznikova V. Mediaciya (poserednycztvo) yak sposib vyrishennya hospodarskyx sporiv. Visnyk KNU. \# 90. 2012. S. 10-15. URL: http://visnyk.law.knu.ua/images/pdf/90_2012.pdf [in Ukrainian]

17. Izarova I.O. Teoretychni zasady cyvilnoho procesu YeS : monografiya. Kyyiv : VD Dakor, 2015. 336 s. [in Ukrainian]

Received: $20 / 05 / 2020$

1st Revision: $15 / 06 / 2020$ Accepted: 25/06/2020

\title{
ALTERNATIVE WAYS TO RESOLVE LABOUR DISPUTES: PRACTICE OF UKRAINE AND THE EU
}

This article explores alternative ways of resolving labour disputes through the analysis of relevant regulations of Ukraine and the Member States of the European Union, in particular, France, Bulgaria and Poland, and compares the relevant regulations in this area by contrasting the provisions of domestic and foreign legislation.

The purpose of the article is to explore the ways to alternatively resolve labour disputes by analyzing the relevant legal doctrine and provisions of domestic and European law, to identify the advantages and disadvantages of such methods as mediation, conciliation, arbitration, to suggest ways to improve existing legislation.

It is noted that the lack of proper legal regulation of alternative dispute resolution today is not the only. Thus, it emphasizes the need to train personnel who could perform the functions of mediators in labour disputes, as well as the need to conduct a comprehensive information policy to inform the public about the benefits of alternative dispute resolution as opposed to litigation, to which the author, in particular, relates the speed, efficiency and focus on maintaining labour relations. In addition, consideration is given to the feasibility of introducing mandatory pre-trial procedures for the settlement of labour disputes.

The results of the study can be used for further research in the study of alternative ways of resolving labour disputes, and the formulated proposals can be used to improve existing legislation in the field of labour disputes.

Keywords: a labor conflict, mediation, conciliation, arbitration courts, arbitration, a labor dispute commission.

Bulletin of Taras Shevchenko National University of Kyiv. Legal Studies, 2020; 2 (113): 66-71

УДК: 349.6

DOI: https:doi.org/10.17721/1728-2195/2020/2.113-13
ISSN 1728-2195

C Taras Shevchenko National University of Kyiv, Publishing center "Kyiv University", 2020

ORCID ID: 0000-0001-7152-0108

Київський національний університет імені Тараса Шевченка, Київ, Україна

\section{ОСОБЛИВОСТІ ПРАВОВОГО СТАНОВИЩА ВИРОБНИКІВ СИРОВИНИ ДЛЯ ДИТЯЧОГО ХАРЧУВАННЯ}

Досліджено правове становище виробників сировини для дитячого харчування в Україні. Установлено, що в законодавстві України відсутній єдиний підхід до визначення поняття "сільськогосподарський товаровиробник", що може призводити до негативних наслідків у правозастосуванні. Висвітлено правові питання загальної, спеціальної та особливої правосуб'єктності виробників сировини рослинного і тваринного походження для дитячого харчування. Установлено, що виробники сільськогосподарської сировини для дитячого харчування наділені спеціальною правосуб'єктністю, що проявляється крізь призму виконання ними обов'язку виробництва якісної та безпечної сільськогосподарської сировини. Проаналізовано сучасне правове становище спеціальних сировинних зон із виробництва сировини, що використовується для виготовлення продуктів дитячого та дієтичного харчування. Наголошено на необхідності встановлення законодавчої заборони на будь-яке застосування пестицидів на території спеціальних сировинних зон. Зазначено, що ті суб'єкти агробізнесу, які провадять свою діяльність у спеціальних сировинних зонах, спроможні забезпечити виробників дитячого харчування екологічно чистою та безпечною сировиною тваринного і рослинного походження. Водночас такі суб'єкти майже не мають жодних переваг перед сільськогосподарськими товаровиробниками без статусу спеціальної сировинної зони. Акцентовано увагу на негативній тенденції скорочення кількості спеціальних сировинних зон із виробництва сировини, яка використовується для виготовлення продуктів дитячого харчування. Констатовано, що існує нагальна потреба у створенні дієвого механізму державної підтримки суб'єктів агробізнесу, які отримали статус спеціальної сировинної зони. Зроблено висновок, що сільськогосподарські товаровиробники, які виробляють сировину у спеціальних сировинних зонах, наділені особливою правосуб'єктністю.

Ключові слова: генетично модифіковані організми, дитяче харчування, сільськогосподарська сировина, сільськогосподарський виробничий кооператив, спеціальна сировинна зона, пестициди й агрохімікати, фермерське господарство, якість і безпечність продуктів харчування.

ВСТУП. Виробництво сільськогосподарської сировини для дитячого харчування є стратегічно важливим напрямом виробничо-господарської економіки України в аграрному секторі. Виробництво якісної та безпечної сільськогосподарської сировини рослинного і тваринно- го походження, яка використовується для виготовлення дитячого харчування, дозволяє гарантувати конституційне право дитини на достатнє харчування, а також підтримувати належний стан продовольчої безпеки держави. На сьогоднішній день існує велике різноманіт- 
тя продукції дитячого харчування, яка виготовляється на основі сільськогосподарської сировини. У законодавстві України залишається невизначеним поняття "виробник сільськогосподарської сировини для дитячого харчування", що ускладнює розуміння правового становища такого суб'єкта агробізнесу.

У юридичній літературі питанням правого становища сільськогосподарських товаровиробників присвятили свої праці О.Д. Бурґер (Костур), Т. О. Коваленко, $\begin{array}{lll}\text { С. І. Марченко, } & \text { В. А. Січевлюк, В. Ю. Уркевич, }\end{array}$ М. М. Чабаненко, Т. М. Чурилова, М.В.Шульга та інші вчені. Питання якості та безпечності сільськогосподарської продукції та продовольчої безпеки досліджували такі науковці, як С.І.Бугера, А. В. Калініченко, Г. С. Корнієнко, К. М. Кравцова, Т. М. Курман, А. М. Статівка, В. С. Шелестов, В. 3. Янчук та ін. Водночас в Україні досі не проводились спеціальні дослідження правового становища виробників сільськогосподарської сировини для дитячого харчування, що зумовлює актуальність теми даної статті.

Метою статті $€$ з'ясування правового становища виробників сільськогосподарської сировини для дитячого харчування в Україні. Об'єктом дослідження $є$ законодавство України, у якому містяться приписи щодо виробників сировини тваринного і рослинного походження для дитячого харчування.

ВИКЛАД ОСНОВНОГО МАТЕРІАЛУ. ПОНЯТТЯ "сільськогосподарський товаровиробник". Для з'ясування особливостей правового становища виробника сільськогосподарської сировини для дитячого харчування як суб'єкта аграрних правовідносин необхідно проаналізувати такі базові поняття, як "суб'єкт права", "суб'єкт аграрного права", "суб'єкт агарних правовідносин". У юридичній науці суб'єкт права розглядається як абстрактне поняття, що означає особу, наділену мінімальним обсягом прав та обов'язків. Суб'єктивні права та юридичні обов'язки суб'єкта права конкретизуються і розвиваються у казуальних суспільних відносинах. У теорії агарного права під суб'єктом аграрного права розуміють особу, визначену законодавством, яка наділена сукупністю прав і обов'язків, достатніх для забезпечення участі в аграрних правовідносинах [1, с. 79]. Усіх суб'єктів аграрного права М. М. Чабаненко поділяє на три групи. До першої групи належать засновані на приватній, державній і комунальній фрормах власності юридичні особи або інші структури, які не мають статусу юридичної особи й головним предметом діяльності яких $€$ виробництво товарної маси продуктів харчування, продовольства і сировини. До другої - підприємницькі структури, діяльність яких спрямована на забезпечення виробничо-господарської діяльності аграрних товаровиробників і заснована на різних формах власності та організаційно-правових формах. Третю групу становлять підприємницькі структури, правосуб'єктність і статутна діяльність яких спрямовані на надання різноманітних фінансово-кредитних, страхових, комерційних, посередницьких та інших послуг для забезпечення підприємницької діяльності сільськогосподарських товаровиробників [2, с. 216].

Деякі науковці вводять поняття "суб'єкти аграрного виробництва". Під суб'єктами аграрного виробництва розуміють насамперед виробників аграрної продукції, тобто сільськогосподарських товаровиробників, незалежно від форм власності та організаційно-правових форм господарювання, і осіб, що ведуть особисте селянське господарство [3, с. 114]. На нашу думку, з аналізу представлених поглядів виявляється проблема різного розуміння одних і тих самих правових явищ i підміни понять. За своєю правовою природою поняття "суб'єкт права" та "суб'єкт правовідносин" не є тотожними. Суб'єкт права не завжди може бути суб'єктом відповідних правовідносин. Тільки з набуттям правосуб'єктності та її реалізацією у конкретних суспільних відносинах, урегульованих правом, він набуває статусу суб'єкта правовідносин.

Крім цього, не є тотожними поняття "сільськогосподарський товаровиробник" та "сільськогосподарське підприємство". Для підтвердження цієї позиції необхідно звернутися до законодавчих дефініцій зазначених понять. Визначення сільськогосподарського товаровиробника міститься у ч. 1 ст. 1 Закону України "Про особливості страхування сільськогосподарської продукції 3 державною підтримкою" від 09.02.2012 № 4391-VI. Під сільськогосподарським товаровиробником розуміється юридична особа, незалежно від організаційно-правової форми, яка займається виробництвом сільськогосподарської продукції та/або розведенням, вирощуванням і виловом водних біоресурсів у внутрішніх водоймах та її переробкою на власних або орендованих потужностях, у тому числі із власновиробленої сировини на давальницьких умовах, і здійснює операції з ії постачання. Схоже визначення містить підп. 14.1.235 п. 14.1 ст. 14 Податкового кодексу України, проте, на відміну від згаданого вище закону, до сільськогосподарських виробників віднесено і фрізичних осіб-підприємців. Дещо поіншому сфрормульовано визначення сільськогосподарського товаровиробника в Законі України "Про стимулювання розвитку сільського господарства на період 2001-2004 років" від 18.01.2001 № 2238-ІІ. Так, у ст. 1 до сільськогосподарських товаровиробників віднесено фізичних та юридичних осіб, які займаються виробництвом сільськогосподарської продукції, переробкою власновиробленої продукції та її реалізацією. Згаданий закон дає десрініцію поняття "сільськогосподарське підприємство", яке визначається як юридична особа, основним видом діяльності якої $є$ вирощування та переробка сільськогосподарської продукції, виручка від реалізації якої становить не менше 50 \% від загальної суми виручки.

Таким чином, констатуємо, що в законодавстві відсутній єдиний підхід до визначення поняття "сільськогосподарський товаровиробник", що, у свою чергу, може породжувати негативні наслідки безпосередньо у правозастосуванні. На нашу думку, необхідно виходити 3 конкретних правовідносин, у яких перебувають зазначені суб'єкти, і застосовувати той закон, сфрера дії якого розповсюджується на відповідні правовідносини.

Загальна правосуб'єктність виробників сільськогосподарської сировини для дитячого харчування. Виробники сільськогосподарської сировини для дитячого харчування наділені загальною та спеціальною правосуб'єктністю. Загальна правосуб'єктність виробників зазначеної сировини регулюється такими базовими нормативно-правовими актами, як Господарський кодекс України від 16.01.2003 № 436-IV, Цивільний кодекс України від 16.01.2003 № 435-IV, закони України "Про господарські товариства" від 19.09.1991 № 1576-XII, "Про акціонерні товариства" від 17.09.2008 № 514-VI, "Про товариства з обмеженою відповідальністю" від 06.02.2018 № 2275-VIII, "Про фермерське господарство" від 19.06.2003 № 973-IV, "Про кооперацію" від 10.07.2003 № 1087-IV, "Про сільськогосподарську кооперацію" від 17.07.1997 № 469/49-ВР, "Про державну реєстрацію юридичних осіб, фрізичних осіб-підприємців та громадських фоормувань" від 15.05.2003 № 55-IV тощо.

Ураховуючи різноманіття сільськогосподарської сировини, яка використовується для виготовлення дитячого харчування, вимоги до суб'єктів виробництва такої сировини містяться в диференційованих нормативно- 
правових актах аграрного законодавства. Виробництво сільськогосподарської сировини для дитячого харчування може здійснюватися в таких організаційноправових формах суб'єктів аграрного підприємництва: фермерське господарство, аграрне господарське товариство, сільськогосподарський виробничий кооператив, державне сільськогосподарське підприємство, фрізична особа-підприємець, а також особа, яка веде особисте селянське господарство.

Відповідно до ст. 1 Закону України "Про фермерське господарство" фермерське господарство $€$ формою підприємницької діяльності громадян, які виявили бажання виробляти товарну сільськогосподарську продукцію, здійснювати ії переробку та реалізацію з метою отримання прибутку на земельних ділянках, наданих їм у власність та/або в користування, у тому числі в оренду, для ведення фермерського господарства, товарного сільськогосподарського виробництва, особистого селянського господарства відповідно до закону. За Законом України "Про фермерське господарство" основними ознаками такої форми підприємницької діяльності є: 1) право на створення фермерського господарства має дієздатній громадянин, який досяг 18-річного віку та виявив бажання створити фермерське господарство; 2) діяльність фермерського господарства спрямована на виробництво, переробку та реалізацію товарної сільськогосподарської продукції з комерційною метою; 3) наявність у власності та/або в користуванні фермерського господарства земельної ділянки для ведення фермерського господарства, товарного сільськогосподарського виробництва, особистого селянського господарства; 4) фермерське господарство може були створене у формі юридичної особи або без створення такої; 5) відносини членства у фермерському господарстві базуються на родинних і сімейних зв'язках із можливістю використання найманої праці.

Відповідно до положень ст. 80 Господарського кодексу України до господарських товариств належать: акціонерні товариства, товариства з обмеженою відповідальністю, товариства з додатковою відповідальністю, повні та командитні товариства. Слід зазначити, що серед сільськогосподарських товаровиробників, які створені та діють у формі господарського товариства, переважають акціонерні товариства і товариства з обмеженою відповідальністю. Акціонерним товариством $\epsilon$ таке господарське товариство, яке має статутний капітал, поділений на визначену кількість акцій однакової номінальної вартості, і несе відповідальність за зобов'язаннями тільки майном товариства, а акціонери несуть ризик збитків, пов'язаних із діяльністю товариства, у межах вартості належних їм акцій, крім випадків, визначених законом. Товариством з обмеженою відповідальністю $€$ господарське товариство, що має статутний капітал, поділений на частки, розмір яких визначається установчими документами, і несе відповідальність за зобов'язаннями тільки своїм майном. При цьому учасники несуть ризик збитків, пов'язаних із діяльністю товариства, у межах своїх внесків за умови повної їх сплати.

Проведений аналіз аграрного законодавства дає підстави для висновку, що агарні господарські товариства, які вирощують сільськогосподарську сировину для виробництва дитячого харчування, мають таку ж загальну правосуб'єктність, як інші господарські товариства в інших сферах економіки. Єдиною відмінністю господарських товариств у сфрері агробізнесу $є$ спрямованість їхньої господарської діяльності, тобто її здійснення у сфері товарного аграрного виробництва.

На відміну від аграрних господарських товариств, така організаційно-правова форма господарювання як сільськогосподарський виробничий кооператив має власну аграрну специфіку як особливий різновид кооперативів. Відповідно до Закону України "Про сільськогосподарську кооперацію" сільськогосподарським виробничим кооперативом $€$ сільськогосподарський кооператив, який утворюється шляхом об'єднання фізичних осіб, які є виробниками сільськогосподарської продукції, для провадження спільної виробничої та іншої господарської діяльності на засадах їх обов'язкової трудової участі з метою одержання прибутку. Основними кваліфікуючими ознаками сільськогосподарського виробничого кооперативу відповідно до законодавства $є:$ 1) він створюється шляхом об'єднання фрізичних осіб-виробників сільськогосподарської продукції; 2) управління справами кооперативу здійснюється на основі відносин членства (один член - один голос); 3) членами сільськогосподарського виробничого кооперативу можуть бути лише фрізичні особи, які внесли вступний внесок і пай, визначені статутом; 4) необхідною є особиста трудова участь членів кооперативу в його діяльності; 5) наявність інституту кооперативних виплат; 6) обов'язкова наявність пайового та неподільного фондів тощо.

Спеціальна правосуб'єктність виробників сільськогосподарської сировини для дитячого харчування. Спеціальна правосуб'єктність виробників сільськогосподарської сировини для дитячого харчування в Україні може бути розглянута крізь призму виконання ними основного обов'язку - забезпечення виробництва якісної та безпечної сільськогосподарської продукції. Основними нормативно-правовими актами у сфері виробництва якісної та безпечної сільськогосподарської сировини для дитячого харчування $€$ закони України "Про дитяче харчування" від 14 вересня 2006 № 142-V, "Про основні принципи та вимоги до безпечності та якості харчових продуктів" у редакції від 22.07.2014 № 1602-VII, "Про карантин рослин" у редакції від 19.01.2006 № 3369-IV, "Про ветеринарну медицину" у редакції від 16.11.2006 № 361-V, "Про державний контроль за дотриманням законодавства про харчові продукти, корми, побічні продукти тваринного походження, здоров'я та благополуччя тварин" від 18.05.2017 № 2042-VIII, "Про пестициди та агрохімікати" від 02.03.1995 № 86/95-ВР тощо.

Як показує проведений аналіз приписів аграрного законодавства, Закон України "Про основні принципи та вимоги до безпечності та якості харчових продуктів" установлює загальні вимоги до виробників сільськогосподарської сировини для дитячого харчування щодо безпечності та якості відповідної сировини. Зокрема, зазначеним законом передбачені обов'язки операторів ринку щодо дотримання вимог закону щодо гігієнічних вимог до харчових продуктів на всіх стадіях виробництва та обігу; реєстрування потужностей, коли це передбачено законом; забезпечення виконання вимог законодавства про безпечність та окремі показники якості харчових продуктів тощо. Законом установлено, що для здійснення діяльності, пов'язаної 3 виробництвом та/або зберіганням харчових продуктів тваринного походження, необхідно отримати експлуатаційний дозвіл. Однак такий обов'язок не поширюється на операторів ринку, які здійснюють первинне виробництво харчових продуктів тваринного походження. Незважаючи на це, для гарантування безпечності та якості харчових продуктів тим суб'єктам господарювання, на яких не поширюється обов'язок отримання експлуатаційного дозволу, необхідно проходити процедуру державної реєстрації потужностей із виробництва й обігу харчових продуктів.

Крім цього, у ст. 32 Закону України "Про основні принципи та вимоги до безпечності та якості харчових 
продуктів" установлено, що харчові продукти, які $€$ на території України, мають відповідати вимогам законодавства про безпечність та окремі показники якості харчових продуктів. Для виконання поставленої мети передбачено низку загальних правових норм, які, зокрема, відображені у ст. 36-37 та ст. 40 зазначеного вище закону. Такі норми містять правила поведінки суб'єктів агробізнесу щодо обігу харчових продуктів на агропродовольчих ринках, а також установлюють гігієнічні вимоги до первинної сільськогосподарської сировини.

Законом України "Про карантин рослин" установлено обов'язок осіб, які здійснюють господарську діяльність, пов'язану із виробництвом, переробкою, зберіганням, транспортуванням, торгівлею рослинами і рослинними продуктами, виконувати фрітосанітарні правила та здійснювати фрітосанітані заходи, проводити систематичний моніторинг земельних угідь, які належать їм на правах власності або користування, а також потужностей, на яких здійснюється виробництво та/або обіг рослин, продуктів рослинного походження з метою виявлення регульованих шкідливих організмів. У сучасних умовах відповідні фрітосанітарні правила та заходи мають важливе значення для забезпечення як продовольчої безпеки держави взагалі, так і безпечності дитячого харчування зокрема.

Слід зазначити, що на правосуб'єктність сільськогосподарських товаровиробників мають істотний вплив також приписи Закону України "Про ветеринарну медицину". Зокрема, указаним законом передбачений спеціальний правовий статус для осіб, які займаються утриманням та обігом тварин, що вирощуються як для власного споживання, так і для промислового використання. Юридичні та фрізичні особи, діяльність яких пов'язана 3 утриманням та обігом тварин, зобов'язані: 1) забезпечувати, щоб тварини, яких вони вирощують, утримують та/або здійснюють їхній обіг, не мали хвороб, що підлягають повідомленню; 2) охороняти здоров'я і благополуччя тварин; 3) виконувати вимоги щодо ідентифікації тварин; 4) вести облік кожної продуктивної тварини стосовно придбання та застосування ветеринарних лікарських засобів, ветеринарних імунобіологічних засобів і лікувальних кормів та зберігати ці записи не менше трьох років тощо.

У юридичній літературі наголошується, що застосування принципу екологічної орієнтованості, урахування необхідності при законотворенні у природоохоронній сорері керуватися передусім правами людини на безпечне навколишнє середовище вбачається ключовим для України при здійсненні правотворчої діяльності [4, с. 41]. У цьому зв'язку важливе значення мають приписи Закону України "Про пестициди і агрохімікати". Основним принципом державної політики у сфері застосування пестицидів та агрохімікатів є пріоритетність збереження здоров'я людини і охорони навколишнього природного середовища щодо економічного ефекту від їх застосування. У ст. 18 зазначеного закону міститься припис щодо відповідності сільськогосподарської сировини до санітарних вимог стосовно максимальних меж залишків пестицидів і агрохімікатів.

Аналогічну регулятивну мету переслідують правові приписи Закону України "Про державну систему біобезпеки при створенні, випробуванні, транспортуванні та використанні генетично модифікованих організмів" від 31.05.2007 № 1103-V. Водночас, як зазначає В. Ю. Уркевич, навіть побіжне ознайомлення з цим документом дозволяє стверджувати, що його приписи мають загальний характер, не повною мірою відповідають законодавству $€ С$ щодо обігу ГМО, більше того, існуючі нормативні приписи майже не виконуються [5, с. 67].
Основну частину раціону дітей віком від народження до трьох років становлять молочні продукти. Виробництво молока, молочної сировини та молочних продуктів регулюється Законом України "Про молоко та молочні продукти" від 24.06.2004 № 1870-IV. Виробником молока та молочної сировини згідно зі згаданим законом визнається юридична особа незалежно від форми власності, фрізична особа-суб'єкт підприємницької діяльності, особисте селянське господарство, фізична особа, яка утримує корів, овець, кіз, буйволиць, кобил і виробляє молоко та молочну сировину.

Не менш важливою складовою раціону харчування дитини є злакові суміші. Виробництво зерна як сільськогосподарської сировини для дитячого харчування регулюється Законом України "Про зерно та ринок зерна в Україні" від 04.07.2002 № 37-IV. Виробництво зерна визначається як діяльність сільськогосподарських товаровиробників, що пов'язана з вирощуванням зерна, забезпеченням внутрішніх потреб України в насіннєвому матеріалі, зерні для продовольчих, фуражних і технічних цілей, поліпшенням його якості, створенням експортного потенціалу ринку зерна, а також гарантуванням продовольчої безпеки держави за рахунок розвитку власного зернового господарства. Суб'єктами виробництва зерна в Україні визнаються власники, орендарі та користувачі земельних ділянок, які використовуються для виробництва зерна.

Таким чином, можемо стверджувати про наявність спеціальної агарної правосуб'єктності у виробників сільськогосподарської сировини для дитячого харчування, яка реалізується у їхній діяльності при виконанні обов'язку виробництва якісної та безпечної сировини рослинного і тваринного походження.

Особлива правосуб'єктність виробників сільськогосподарської сировини для дитячого харчування. Спеціальним диференційованим нормативноправовим актом у сфері виробництва дитячого харчування, у тому числі виробництва сільськогосподарської сировини для дитячого харчування, є Закон України "Про дитяче харчування" від 14.09.2006 № 142-V.

Закон України "Про дитяче харчування" не містить легального визначення виробника сільськогосподарської сировини для дитячого харчування, так само як i уніфікованих вимог до таких осіб. Натомість у ст. 1 зазначеного закону закріплено дефініцію поняття "виробник дитячого харчування" як юридичної особи, яка здійснює господарську діяльність із виробництва дитячого харчування $з$ метою введення його в обіг. На нашу думку, таке законодавче визначення $€$ дещо звуженим, адже 3 його буквального тлумачення можна зробити припущення, що фрізична особа-підприємець законодавчо не визнається виробником дитячого харчування. Водночас у Єдиному державному реєстрі юридичних осіб, фрізичних осіб-підприємців та громадських формувань зареєстровані фрізичні особи-підприємці, основним видом господарської діяльності яких $€$ виробництво продукції дитячого харчування [6].

Слід зазначити, що в аграрному законодавстві відсутні особливі вимоги до суб'єктів, які мають право виготовляти сільськогосподарську сировину для дитячого харчування. Водночас у ч. 1. ст. 8 Закону України "Про дитяче харчування" встановлено, що у виробництві дитячого харчування застосовується сировина, яка виробляється переважно у спеціальних сировинних зонах.

Станом на 19 липня 2019 року в Реєстр спеціальних сировинних зон включено дев'ять суб'єктів господарювання, які виготовляють сільськогосподарську сировину для дитячого харчування [7]. При цьому такі суб'єкти переважно виробляють молоко та молочну 
сировину, що зумовлено законодавчо передбаченою державною підтримкою тих сільськогосподарських підприємств, які виготовляють у спеціальних сировинних зонах екологічно чисте молоко та молочну сировину для дитячого харчування. 3 вищезазначеного можна дійти висновку, що положення Закону України "Про дитяче харчування" не реалізуються повною мірою, а отже, потребують удосконалення не тільки його приписи, але й механізмі їх реалізації.

Аграрним законодавством передбачено низку додаткових вимог до спеціальних сировинних зон з метою посилення контролю за виробництвом безпечної, якісної та екологічно чистої сільськогосподарської сировини для дитячого харчування. Так, Законом України "Про дитяче харчування" передбачено, що у спеціальній сировинній зоні забороняється будівництво промислових і хімічних об'єктів, а також інша діяльність, яка за результатами оцінки впливу на довкілля може призвести до погіршення стану довкілля. Застосування пестицидів і агрохімікатів провадиться за спеціальними технологіями, що забезпечують отримання продукції, яка відповідає обов'язковим параметрам безпечності, затвердженим відповідно до закону. Наведені приписи Закону не вбачаються обґрунтованими в частині застосування пестицидів у спеціальній сировинній зоні. Адже пестициди - це токсичні речовини, їхні сполуки або суміші речовин хімічного чи біологічного походження, призначені для знищення, регуляції та припинення розвитку шкідливих організмів, унаслідок діяльності яких уражаються рослини, тварини, люди і завдається шкода матеріальним цінностям, а також гризунів, бур'янів, деревної, чагарникової рослинності, засмічуючих видів риб. На нашу думку, дотримуючись принципу пріоритетності життя і здоров'я людини перед економічною доцільністю, необхідно законодавчо встановити заборону на використання пестицидів у спеціальній сировинній зоні.

Порядок надання статусу спеціальної сировинної зони з виробництва сировини, що використовується для виготовлення продуктів дитячого та дієтичного харчування, затверджений Постановою Кабінету Міністрів України від 03.10.2007 № 1195. Зазначений Порядок визначає процедуру надання статусу спеціальної зони 3 виробництва сировини, що використовується для виготовлення дитячого та дієтичного харчування. Згідно 3 чинним законодавством загальними вимогами до спеціальних сировинних зон є: 1) розташування на угіддях, які належать до земель сільськогосподарського призначення; 2) нормативно обґрунтована віддаленість від промислових та інших об'єктів, які можуть забруднювати навколишнє природне середовище; 3) високий рівень родючості земель; 4) відповідність сировини до санітарно-гігієнічних вимог до дитячого та дієтичного харчування, обов'язкових параметрів безпечності та мінімальних специфікацій якості, затверджених центральним органом виконавчої влади з питань охорони здоров'я; 5) наявність документів, що підтверджують реєстрацію виробника сировини у відповідному державному органі ветеринарної медицини.

Зокрема, у спеціальній сировинній зоні забороняється вирощування і використання генетично модифікованих організмів, а також виробництво тваринницької продукції із застосуванням гормональних та інших препаратів штучного походження.

Необхідно звернути увагу на негативну тенденцію скорочення в Україні кількості спеціальних сировинних зон, причиною чого стала відсутність будь-якої державної підтримки. Незважаючи на спеціальний статус суб'єктів, які здійснюють виробництво у спеціальних сировинних зонах, вони не мають жодних суттєвих пе- реваг перед виробниками сільськогосподарської сировини для дитячого харчування. На нашу думку, саме ті суб'єкти агробізнесу, які здійснюють свою діяльність у спеціальних сировинних зонах, спроможні на належному рівні забезпечувати виробників дитячого харчування екологічно чистою сировиною рослинного і тваринного походження. У свою чергу, дитина буде забезпечена харчовою продукцією високого рівня, а національний виробник дитячого харчування зможе достойно конкурувати зі світовими брендами та користуватися довірою у покупців. Усе це можливо за умови створення ефективного механізму державної підтримки виробників як сільськогосподарської сировини, так і готових продуктів дитячого харчування.

Слід також зазначити про необхідність оновлення законодавства про дитяче харчування, оскільки воно не здатне ефективно виконувати свої фрункції з регуляції та охорони суспільних відносин у цій сфері. На нашу думку, доцільно буде використати положення Закону України "Про основні принципи та вимоги до органічного виробництва, обігу та маркування органічної продукції" від 10.072018 № 2496-VIII у частині вимог до сільськогосподарської сировини, а також методів і способів її виробництва.

\section{ВИСНОВКИ}

1) Виробники сільськогосподарської сировини для дитячого харчування наділені загальною правосуб'єктністю як суб'єкти господарювання; спеціальною правосуб'єктністю як сільськогосподарські товаровиробники, основним обов'язком яких $€$ виробництво якісної та безпечної сировини рослинного і тваринного походження; особливою правосуб'єктністю, що виявляється у документально підтвердженій відповідності виробника до умов виробництва сировини, яка використовується для виготовлення продуктів дитячого харчування, тобто у правовому статусі спеціальної сировинної зони.

2) Необхідно встановити заборону використання пестицидів при виробництві сільськогосподарської сировини для дитячого харчування у спеціальній сировинній зоні. Пропонуємо викласти ч. 4 ст. 8 Закону України "Про дитяче харчування" у такій редакції: "Застосування агрохімікатів у спеціальній сировинній зоні здійснюється за спеціальними технологіями, що забезпечують отримання продукції, яка відповідає обов'язковим параметрам безпечності, затвердженим відповідно до закону. У спеціальній сировинній зоні забороняється використання пестицидів".

Список використаних джерел:

1. Асрарне право України : підручник. В. М. Єрмоленко, О. В. Гафурова, М. В. Гребенюк [та ін.] ; за заг. ред. В. М. Єрмоленка. К.: Юрінком Інтер, 2010. С 608.

2. Чабаненко М. М. Правове становище суб'єктів аграрного права й особливості встановлення їхніх прав та обов'язків як елементи галузевого методу аграрного права. Вісник Запорізького національного університету. Юридичні науки. 2014. № 4 (2). С. 214-223.

3. Аграрне право: підручник. В.М. Корнієнко, Г. С. Корнієнко, І. М. Кульчій та ін.; за ред. А. М. Статівки. Харків : Право, 2018. С. 412.

4. Бабенко О. С. Питання адаптації українського законодавства про агрохімікати та пестициди до норм законодавства ЄС. Науковий вісник Херсонського державного університету. 2013. № 1. С. 39-41.

5. Уркевич В. Ю. Правові питання екологізації сільськогосподарського виробництва при використанні ГМО. Від правової охорони природи Української РСР до екологічного права України: зб. тез Всеукр. наук.-практ. Конф., присвяч. пам'яті д-ра юрид. наук., профф. Василя Лук'яновича Мунтяна з нагоди 95-річчя від Дня народж., 26 трав. 2017 р., Київ. М-во освіти і науки України, Київ. нац. ун-т ім. Тараса Шевченка, Юрид. ф-т [та ін.] ; [уклад.: В. В. Носік, А. С. Євстігнєєв, М. П. Кучерова]. Чернівці: Кондратьєв А. В., 2017. С. 66-69.

6. ФОП Боднарчук Віталій Петрович. URL: https://youcontrol.com.ua/ catalog/fop_details/26778092. (дата звернення: 04.05.2020).

7. Реєстр спеціальних сировинних зон. URL: https://minagro.gov.ua/ ua/file-storage/reyestr-specialnih-sirovinnih-zon (дата звернення: 06.05.2020). 
References:

1. Agrarne pravo Ukrayiny' : pidruchny'k V. M. Yermolenko, O. V. Gafurova, M. V. Grebenyuk [ta in.] ; za zag. red. V. M. Yermolenka. K.: Yurinkom Inter, 2010. 608 S. (in Ukrainian).

2. Chabanenko M. M. Pravove stanovy'shhe sub'yektiv agrarnogo prava j osobly'vosti vstanovlennya yixnix prav ta obov'yazkiv yak elementy' galuzevogo metodu agrarnogo prava. Visny'k Zaporiz'kogo nacional'nogo universy'tetu. Yury'dy'chni nauky'. 2014. \# 4(2). S. 214-223 (in Ukrainian).

3. Agrarne pravo: pidruchny'k. V. M. Korniyenko, G. S. Korniyenko, I. M. Kul'chij ta in.; za red. A. M. Stativky'. Xarkiv : Pravo, 2018. S. 412 (in Ukrainian).

4. Babenko O. S. Py'tannya adaptaciyi ukrayins'kogo zakonodavstva pro agroximikaty' ta pesty'cy'dy' do norm zakonodavstva YeS. Naukovy'j visny'k Xersons'kogo derzhavnogo universy'tetu. 2013. № 1. S. 39-41 (in Ukrainian).

5. Urkevy'ch V. Yu. Pravovi py'tannya ekologizaciyi sil's'kogospodars'kogo vy'robny'cztva pry' vy'kory'stanni GMO. Vid pravovoyi oxorony'

R. Shybko, PhD stud. (Law)

Taras Shevchenko National University of Kyiv, Kyiv, Ukraine pry'rody' Ukrayins'koyi RSR do ekologichnogo prava Ukrayiny' : zb. tez Vseukr nauk.-prakt Konf, pry'svyach. pam"yati d-ra yury'd nauk, prof. Vasy'lya Luk'yanovy'cha Muntyana z nagody' 95-richchya vid Dnya narodzh., 26 trav. 2017 r., Ky'yiv. M-vo osvity' i nauky' Ukrayiny', Ky'yiv. nacz. un-t im. Tarasa Shevchenka, Yury'd. f-t [ta in.] ; [uklad.: V. V. Nosik, A. S. Yevstignyeyev, M. P. Kucherova]. Chernivci : Kondrat'yev A. V., 2017. S. 66-69 (in Ukrainian).

6. FOP Bodnarchuk Vitalii Petrovych. URL: https://youcontrol.com.ua/ catalog/fop_details/26778092. (ne znayu yak pravy'l'no poslaty's' na sajt (in Ukrainian).

7. Reyestr special'ny'x sy'rovy'nny'x zon. URL: https://minagro.gov.ua/ ua/file-storage/reyestr-specialnih-sirovinnih-zon (in Ukrainian).

Received: $06 / 05 / 2020$

1st Revision: $11 / 06 / 2020$

Accepted: 25/06/2020

\section{THE LEGAL STATUS OF PRODUCERS OF RAW MATERIALS FOR BABY FOOD}

The article is devoted to the research of legal status of the producers of agricultural raw materials for infant nutrition in Ukraine. It is established that in the legislation of Ukraine there is no single approach to defining the concept of "an agricultural producer", which may create negative consequences in law enforcement. The article highlights the legal issues of general, special and particular legal personality of producers of plant and animal origin for infant nutrition. According to national legislation, producers of agricultural raw materials for baby nutrition are endowed with a special legal personality, which is manifested through the prism of their obligation to produce high-quality and safe agricultural raw materials. The article analyzes the current legal status of special raw material zones for the production of raw materials used for the manufacture of infant nutrition and dietary nutrition. As of 19 July 2019 the Register of Special Raw Zones includes nine businesses that produce agricultural raw materials for baby nutrition. At the same time, such entities mainly produce milk and raw milk, which is due to the statutory state support of those agricultural enterprises that produce ecologically clean milk and raw milk for baby nutrition in special raw material zones. The need to establish a ban on any use of pesticides in special raw material areas is stressed. It is noted that those agribusiness entities that operate in special raw material areas are able to provide baby nutrition producers with environmentally friendly and safe raw materials of animal and plant origin. At the same time, such entities have almost no advantages over agricultural producers without the status of a special raw material zone. The author emphasizes the negative trend of reducing the number of special raw material zones for the production of raw materials used for the manufacture of baby nutrition. Thus, there is an urgent need to create an effective mechanism of state support for agribusiness entities that have received the status of a special raw material zone. The author concludes that agricultural producers who produce raw materials in special raw material zones are endowed with a particular legal personality.

Keywords: agricultural raw materials, agricultural production cooperative, baby food, genetically modified organisms, farming, food quality and safety, pesticides and agrochemicals, special raw material zone.

Bulletin of Taras Shevchenko National University of Kyiv.

Legal Studies, 2020; 2 (113): 71-75

УДК: $\mathbf{3 4 9 . 4 2}$

DOI: https:doi.org/10.17721/1728-2195/2020/2.113-14
ISSN 1728-2195

(C) Taras Shevchenko National University of Kyiv

Publishing center "Kyiv University", 2020 ORCID ID: 0000-0002-8689-2593 Київський національний університет імені Тараса Шевченка, Київ, Україна

\section{ПОНЯТТЯ ТА ОСОБЛИВОСТІ ДОГОВОРУ СКЛАДСЬКОГО ЗБЕРІГАННЯ ЗЕРНА}

3'ясовано характерні ознаки договору складського зберігання зерна, обґрунтовано перелік його істотних умов, досліджено правову природу й особливості складських документів на зерно. Виявлено недоліки правового регулювання укладення та виконання договорів складського зберігання зерна, а також обґрунтовано пропозиції з метою їх усунення. Установлено, що правова природа договору складського зберігання зерна виявляється в тому, що він є: договором про надання послуг; публічним договором; письмовим договором; двостороннім договором; зазвичай відплатним договором; строковим договором; реальним договором; договором приєднання; укладається у спеціальному порядку. Доведено, що істотними умовами договору складського зберігання зерна є: предмет договору (послуги зі складського зберігання зерна із збереженням його якості та недопущення втрат вище природних); об'єкт договору (зерно певного виду, класу, кількості, яке зазначене в договорі складського зберігання зерна); термін договору (із зазначенням певного часового проміжку або без указівки такого, що зумовлює дію договору до першої вимоги поклажодавця). 3 метою спрощення обігу складських документів на зерно та зменшення рівня зловживань на ринку зерна пропонується внести зміни до статті 961 Цивільного кодексу України, Закону України "Про зерно та ринок зерна в Україні" і Закону України "Про сертифіковані товарні склади та прості і подвійні складські свідоцтва", передбачивии можливість видачі складських свідоцтв у електронній формі.

Ключові слова: договір складського зберігання зерна; зберігання зерна; зерно; подвійне складське свідоцтво; просте складське свідоцтво; складська көитанція; складські документи на зерно.

ВСТУП. Однією із пріоритетних культур у сільському господарстві України є зерно. У Законі України "Про зерно та ринок зерна в Україні" від 4 липня 2002 р. зерно визначається як плоди зернових, зернобобових та олійних культур, які використовуються для харчових, насіннєвих, кормових і технічних цілей. Особливості зерна як цінної сільськогосподарської сировини зумовлюють особливості його зберігання, що впливає й на специфріку правового регулювання у зазначеній сфрері.
Зокрема, за даними ФАО, втрати зерна і зернопродуктів при зберіганні щороку становлять 10-15\%. Приміром, у світі від комірних шкідників втрачається стільки зерна, що ним можна було б прогодувати 135 млн осіб [1].

До особливостей діяльності у сфері складського зберігання зерна можна віднести те, що передача зерна на зберігання оформлюється спеціальними правовими актами: договором складського зберігання зерна та складськими документами на зерно. 